\title{
Do Crime-Related Expenditures Crowd Out Higher Education Expenditures?
}

\author{
Michael L. Marlow, Alden F. Shiers \\ California Polytechnic State University
}

\begin{abstract}
Fears about insufficient public education spending are often expressed in the area of higher education, whereby it is often argued that increases in expenditures on crime-related programs crowd out expenditures on higher education. This view suggests that higher education and crimerelated programs directly compete for government expenditures so that what one program gains the other must lose as in a zero-sum game. A competing hypothesis is that higher crime-related spending leads to higher taxes or public debt issuance or to lower spending on programs other than higher education. We estimate a three-equation model of spending on crime-related programs, spending on higher education, and the crime rate from which we directly test whether spending on crime-related programs and higher education influence each other. Our empirical analysis provides weak evidence that crime-related programs have crowded out spending on higher education.
\end{abstract}

\section{INTRODUCTION}

Widely observed increases in government spending on crime-related programs have been a source of great concern to proponents of public education spending. The Bureau of Justice Statistics (1997) reported that, in fiscal 1992, $\$ 94$ billion was spent on crime-related programs by state, local, and federal governments. Crime-related programs are activities that include police protection, jails and prisons, and the courts. On a per capita basis in 1992, these governments spent $\$ 368$, an increase of $59 \%$ over 1987 . State and local governments account for roughly $85 \%$ of crime-related expenditures; however, from 1987 to 1992 the federal government increased its spending at more than twice the rate of state and local governments.

In 1994, California voters passed the "three strikes and you're out" legislation that has led many proponents of education spending to fear that if it leads to higher crime-related expendituresespecially those related to incarceration of criminals-rapid reduction of expenditures on education will surely follow. A RAND Corporation study (Greenwood et al. 1994) predicted that implementation of California's three strikes law will carry a price tag of $\$ 5.5$ billion more in public spending. With more states restricting parole, and as more states consider legislation similar to California's three strikes law, states appear to be undertaking growing commitments toward funding of crime-related programs. 
Fears about insufficient public education spending are often expressed in the area of higher education. Although some states may attempt to insulate elementary and secondary education spending from other influences such as higher demands placed on corrections or law enforcement by establishing minimum funding levels, higher education does not usually receive similar protection. It is therefore not surprising that proponents of higher education spending view the expansion of crime-related spending with great trepidation. Whereas a commonly expressed concern is that increases in higher crime-related spending crowd out spending on public education, another concern is that fewer education dollars today leads to higher future crime rates, which in turn will further crowd out education spending in the future. This latter concern therefore asserts that budget policy that skimps on education spending to fund more spending on crime-related programs is short-run myopic in that it leads to higher longer run public spending on crime-related programs and still fewer future dollars on education.

This article examines the relationship between expenditures of public institutions of higher education and public spending on crime-related programs. As just discussed, it is often alleged that education and crime-related programs directly compete for government expenditures, so that what one program gains the other must lose as in a zero-sum game. Proponents of this view, then, hypothesize that higher expenditures on crime-related programs crowd out expenditures on higher education. A competing hypothesis is that spending on these two public programs are unrelated. For instance, higher crime-related spending may lead to higher taxes or public debt issuance or to reduction in spending on non-crime-related programs.

This article examines whether state and local expenditures on crime-related programs crowd out expenditures on public higher education. We examine the relationship between spending on higher education and crime-related programs between 1985 and 1992. Over this period, public spending on crime-related programs as a percentage of gross state product (GSP) rose from 0.93 to 1.17 while public spending on higher education as a percentage of GSP fell from 2.17 to 1.96. Whether these trends are a result of crime-related programs crowding out public spending on higher education is an empirical question that is the focus of our article. We estimate a three-equation model of spending on crime-related programs, spending on higher education, and the crime rate from which we directly test whether spending on crime-related programs and higher education influence each other.

\section{PREVIOUS STUDIES}

Little research has been conducted in the area of crowding out among programs of state and local governments. Our review of this literature indicates little or no evidence that supports the hypothesis that higher crime-related funding, or funding of any program for that matter, crowds out funding on education. Brazer and McCarty (1987) tested the "municipal overburden" hypothesis that high demand for municipal services lowers demand for public elementary and secondary education. This hypothesis suggests that those areas, primarily urban, that require relatively higher expenditures directed toward dealing with poverty, aged, housing, and crime will have fewer resources available for education funding. No empirical support for the municipal overburden hypothesis was found in cases of per pupil funding among school districts in Connecticut, New Jersey, and Virginia. However, several cases were reported in which a positive 
correlation exists between municipal and education spending, but these are opposite in direction to the predictions of the municipal overburden hypothesis.

Toutkoushian and Hollis (1998) argued that various groups compete for public funding and therefore may potentially explain variation in public spending on higher education across states. They used the proportion of a state's population aged 18 years and younger as a proxy for the competing interest group for K-12 education and the proportion of the population aged 65 and older as a proxy for Medicaid demand. They also considered the ratio of prisoners to population as a proxy for the competing interest group for corrections. They found no evidence that public spending on prisoners or K-12 education crowds out public spending on higher education. However, Hoenack and Pierro (1990) found that state spending on higher education was negatively related to the proportion of a state's population aged 65 and older-thus supporting the view that a competing interest group succeeds in lowering spending on higher education.

Fossett and Wyckoff (1996) examined the impact of rising Medicaid spending on public elementary and secondary education spending. Whereas an inverse relationship is found on data from 47 states from 1980 through 1990, the results are not statistically significant and therefore provide no support for the crowding out hypothesis. McCarty and Schmidt (1997) examined interactions between six spending programs of state governments for evidence of crowding out over 1984 to 1994. The programs were elementary and secondary education, higher education, welfare, health and hospitals, corrections, and miscellaneous. A vector autoregression (VAR) model was used to examine whether changes in one program are correlated with changes in other programs, either over time or contemporaneously. No evidence of crowding out was found and, in most cases, when a program's funding rose above trend, it had no significant influence on future spending on other programs. However, deviations from trend had significant influences on future own-program spending, which may indicate that higher above-trend spending in one program is funded through higher tax revenues than through spending reductions in other programs.

\section{EDUCATION AND CRIME-RELATED SPENDING EQUATIONS}

Expenditures on public programs are determined through the political process between voters and policy makers within the budget (spending, tax, and debt) process. Education and crime-related expenditures are determined along with expenditures in other budget categories, and the total budget is then the sum of its component parts. Various demographic (e.g., age distribution), economic (e.g., unemployment rates), and cultural (e.g., past crime rates, ethnic diversity) characteristics influence demand for various spending programs.

The following models of cross-state higher education and crime-related spending are estimated:

1. $\operatorname{EDEXP}_{i}=f\left(\mathrm{CRIME}_{i}, Y_{i}, \mathrm{EDUC}_{i}, \mathrm{METRO}_{i}, \mathrm{STUDENT}_{i}, \mathrm{COLLEGES}_{i}\right.$, DIVERSITY $_{i}, \quad$ OUTRATE $_{i}$ $\operatorname{PARTY}_{i}$ )

2. $\mathrm{CRIME}_{i}=f\left(\mathrm{EDEXP}_{i}, \mathrm{CR}_{i}, \mathrm{CCR}_{i}, \mathrm{DOM}_{i}, \mathrm{PARTY}_{i}\right)$



See Table 1 for a description of the variables and Table 2 for summary statistics of key variables. 
Reviewing the spending trends in Table 2, we see that average higher education spending as a percentage of GSP declined from 1985 to 1992 as average crime-related spending rose as a percentage of GSP. As percentages of GSP, crime-related spending in 1992 averaged 1.17, with a low of 0.69 (West Virginia) and a high of 1.92 (Florida). In 1985, crime-related spending as a percentage of GSP averaged 0.93, with a low of 0.60 (North Dakota) and a high of 1.55 (New York). Higher education spending as a percentage of GSP in 1992 averaged 1.96, with a low of 0.99 (Massachusetts) and a high of 3.36 (Montana). In 1985, it averaged 2.17, with a low of 0.94 (Alaska) and a high of 3.59 (Iowa). Over this period, then, public spending on higher education as a percentage of GSP fell roughly 10 percent as public spending on crime-related programs as a percentage of GSP rose by roughly 26 percent.

\section{DEPENDENT VARIABLES}

The dependent variables in the estimated equations reported below are higher educational expenditures (as percentages of GSP), $\mathrm{EDEXP}_{i}$; crime expenditures (as percentages of GSP), $\mathrm{CRIME}_{i}$; and the crime rate, $\mathrm{CR}_{i}$. The equations were also estimated using higher education expenditures per student and crime expenditures per capita as dependent variables. To conserve space, these results are not displayed in tables, but the differences resulting from the choice of dependent variables are discussed below.

\section{HIGHER EDUCATION SPENDING EQUATION}

Crime-related spending is included in the higher education spending equation to test the hypothesis that the two are intertwined in the public budget. A negative relation would suggest that higher crime-related spending crowds out higher education spending. A positive relation would suggest that higher spending on crime-related programs leads to higher spending on higher education or that states that allocate relatively many resources to crime-related programs also allocate relatively many resources to higher education programs. No relationship would suggest that the two spending programs are not linked within the public budget.

The median-voter theorem predicts that median voters dominate spending decisions, and therefore median family income, $Y_{i}$, ishypothesized to be positively related to higher education spending. Hoenack and Pierro (1990), Strathman (1994), and Toutkoushian and Hollis (1998) found that per capita (or median) income exerts significant and positive effects on higher education spending.

Voters with more education are hypothesized to vote for larger higher education budgets and therefore a positive coefficient is hypothesized for $\mathrm{EDUC}_{i}$, percentage of population with at least high school degrees. Population density, $\mathrm{METRO}_{i}$, measures the percentage of the population living in metropolitan areas and, because production costs are commonly believed to be higher in metropolitan areas, it is hypothesized to be positively related to education spending. The student (in higher education) percentage of the population, STUDENT ${ }_{i}$, controls for cross-state differences in student populations and is hypothesized to exert positive influences on education spending because higher values may reflect greater student and parental demands for education. ${ }^{4}$

The relationship between numbers of institutions of higher education and educational expenditures is theoretically indeterminate. Substantial economies of scale could be unexploited when there are relatively many schools so that a greater number of schools is associated with higher expenditures. 
But, a large number of schools could also be an indication of vigorous competition with educational services delivered at lower cost. The Leviathan model of Brennan and Buchanan (1980) would predict that fewer schools lead to greater higher education spending due to less intergovernmental competition in the higher education market. The hypothesized sign on COLLEGES ${ }_{i}$, numbers of public institutions per 1,000 students, is therefore an empirical question. ${ }^{6}$

The ethnic diversity of a state's population, DIVERSE $_{i}$, is expected to be positively related to educational expenditures. An ethnically diverse population may require special or remedial education programs that increase expenditures per pupil. An index of diversity was created for each state using race/ethnic groups reported by the Census Bureau: White-Hispanic, BlackHispanic, American Indian, Eskimo, Aleut-Hispanic, Asian Pacific Islander-Hispanic, White nonHispanic, Black non-Hispanic, Aleut non-Hispanic, and Asian Pacific Islander non-Hispanic. The diversity index was calculated as the sum of the squared percentage of the population of each group. The greater the diversity index, the less racially/ethnically diverse a state's population. A negative effect, or that a more diverse population leads to higher expenditures, is therefore hypothesized.

Clotfelter (1976) found that states with higher rates of out-migration of (higher education) graduates will provide less support for student-related spending. States with higher likelihood of out-migration were found to have lower per capita expenditures. This result is argued to be consistent with the view that governments spend less when they anticipate higher benefit losses due to out-migration of graduates and thus suggests that higher education spending is consistent with maximization of community welfare. Stratham (1994) also reported evidence that spending on higher education by state legislatures is influenced by expected future losses in benefits due to outmigration. He also argued that tuition increases often make up for lower spending on higher education due to out-migration.

The rate of population out-migration, $\mathrm{OUTRATE}_{i}$, measures the effect of people leaving the state on higher-education spending. Out-migration of graduates reduces the benefits to the state of providing public education, and state policy makers may respond by reducing higher education funding. Therefore, the rate of out-migration is hypothesized to display a negative relationship with public expenditures on higher education.

The political party of the governor, $\operatorname{PARTY}_{i}$, controls for the possibility of different funding priorities of the two major political parties. This is a dummy variable equal to 1 if the governor was a Republican and 0 if the governor was a Democrat. If the election of a Republican governor results in an increase in crime spending and a decrease in higher education spending, then the estimated coefficient would be negative in the education spending equation and positive in the crime spending equation. ${ }^{7}$

\section{CRIME SPENDING EQUATION}

Spending on higher education is included in the crime spending equation to test the hypothesis that the two are interrelated in the public budget. A negative relation would suggest that increases in higher education spending crowd out crime spending. A positive relation would suggest that increased spending on higher education leads to higher spending on crime or that big spenders on 
crime are also big spenders on higher education. No relationship would suggest no linkage between the two programs.

The crime rate, $\mathrm{CR}_{i}$, and its change over the previous 3 years, $\mathrm{CCR}_{i}$, are hypothesized to exert positive influences on crime spending. Higher crime rates and higher recent increases in crime rates are expected to raise crime-related spending as more resources are devoted to enforcement, court costs, incarceration, and prevention areas of public spending. As crime rates rise, the public may also demand higher expenditures; and given criminal codes and sentencing policies, greater crime activity results in higher public crime-related expenditures.

Dominance of crime-related employees in the population, $\mathrm{DOM}_{i}$, controls for two possible effects on spending. Relatively more employees should lead to higher payrolls and therefore higher spending as well. Also, crime-related employees are a special interest group with an interest in promoting spending on crime-related programs, and therefore they should represent a powerful pressure group on the political process that determines public budgeting when their numbers are larger. Both effects suggest a positive influence from $\mathrm{DOM}_{i}$, and therefore higher shares of crime-related employees are hypothesized to cause higher spending on crime-related programs. Whereas the average percentage of crime-related employees in the population was 0.56 in 1992 (0.50 in 1985), its range runs from a high of 0.85 (New York ) to a low of 0.34 (West Virginia). PARTY $_{i}$ is included to control for the political party of the governor as discussed above in the education spending equation.

\section{CRIME RATE EQUATION}

Crime-related expenditures are hypothesized to exert an inverse influence on the crime rate, as increased current expenditures on police protection and corrections are expected to reduce the crime rate. Effects of past increases in crime expenditures are captured in the lagged crime rate.

The ethnic diversity of a state's population, $\operatorname{DIVERSE}_{i}$, is hypothesized to influence crime rates, based on the expectation that a more ethnically diverse population creates greater cultural conflicts and tensions that result in higher crime rates than does a society with less diversity. The previous year's crime rate, $\mathrm{CR}_{i-1}$, is expected to exert a positive influence on the crime rate.

It is often asserted that poverty breeds crime, so median income is included in the crime rate equation to capture cross-state differences in income levels. It could also be the case that highincome states attract criminals, and so the expected sign on median income is indeterminate.

We hypothesize that the more youthful the population, the higher crime rates are, because a disproportionate share of crimes are committed by juveniles and young adults. We include the following population variables: MID1 ${ }_{i}=$ percentage of population aged 18 to 24 and MID2 ${ }_{i}=$ percentage of population aged 25 to 44 . Higher values of both variables are expected to raise crime rates because a majority of crimes are committed within these age brackets. Median age, $\mathrm{MEDAGE}_{i}$,is used to control for differences in median ages across the states.

The civilian unemployment rate, $\mathrm{UE}_{i}$, is hypothesized to be positively related to crime rates because, in those states with relatively fewer jobs, there may be a greater incentive for criminal activity. Hoenack and Pierro (1990), Strathman (1994), and Toutkoushian and Hollis (1998) found 
that higher unemployment rates lower higher education spending. We hypothesize that the 3-year change in the unemployment rate, $\mathrm{CUE}_{i}$, exerts a positive influence on crime rates because the higher a recent increase in unemployment, the greater the incentive for criminal activity. Use of $\mathrm{CUE}_{i}$ also controls for the fact that some states have persistently high or low unemployment rates, as influenced by geographic or industrial characteristics, and therefore the very fact that a state has a relatively high unemployment rate does not necessarily suggest the same event when some states have persistently high unemployment rates and others have high unemployment rates that are more transitory in nature.

\section{ESTIMATION}

The two-stage least squares (TSLS) technique is used to estimate the spending equations and the crime rate equation because each equation contains dependent variables as right-hand-side variables. Estimation of simultaneous equations using ordinary least squares (OLS) produces biased and inconsistent estimates of the coefficients. The simultaneity bias associated with OLS usually results in an upward bias of the estimated coefficients on the explanatory variables. TSLS is commonly used to mitigate the bias and avoid the inconsistency of OLS, and that is the estimation technique used here.

Equations are estimated for 1992 and 1985, using $i=1,2, \ldots 50$ states. The latest year for which crime data are available is 1992, and comparable data are available for 1985 , so the time periods can be easily compared. Significance of estimated coefficients is based on two-tailed tests at the .01,.05, and 10 levels. Data for $\operatorname{EDEXP}_{i}, \mathrm{STUDENT}_{i}$, and SCHOOLS $i$ are obtained from the Digest of Education Statistics (National Center for Education Statistics 1992, 1993). Data for $Y_{i}, \mathrm{EDUC}_{i}, \mathrm{METRO}_{i}, \mathrm{CR}_{i}$, $\mathrm{CCR}_{i}, \mathrm{UE}_{i}$, and $\mathrm{CUE}_{i}$ are obtained from the Statistical Abstract of the United States (U.S. Department of Commerce n.d.). Data for $\mathrm{CRIME}_{i}$ and $\mathrm{DOM}_{i}$ are obtained from Sourcebook of Criminal Justice Statistics (Bureau of Justice Statistics n.d.) and Justice Expenditure and Employment Extracts, 1992 (Bureau of Justice Statistics 1997). Data on MEDAGE $i$, MID1 $_{i}$, MID2 $_{i}$, DIVERSITY $_{i}$, and OUTRATE $i$ are obtained from U.S. Census population estimates.

Table 3 displays TSLS estimates of our three-equation model for 1992 and 1985 data. Let us discuss the first three columns, which display the estimates for 1992. Total crime spending has a negative and significant effect on education spending, which is consistent with the crowding-out hypothesis, but education spending does not exert a statistically significant influence on crime-related spending. Therefore, the 1992 data suggest some support for the hypothesis that increases in spending on crime-related programs have led to a reduction in spending on higher education.

In the education spending equation, significant influences are crime-related spending (negative) and student share of the population (positive, as hypothesized). In the crime spending equation, significant influences are the contemporaneous crime rate (positive, as hypothesized), the 1989 to 1992 change in the crime rate (negative), employee dominance (positive, as hypothesized), and the party dummy variable (positive). The positive sign on the party dummy indicates that in states led by Republican governors, crime-related spending as a percentage of GSP was greater than in states led by Democratic governors. Estimation of the crime rate equation indicates that the previous year's crime rate exerts a significant positive influence on the contemporaneous crime rate. 
Interestingly, crime-related spending does not exert a statistically significant contemporaneous influence on the crime rate.

The last three columns of Table 3 display equation estimates for 1985. No evidence of any relationship is found between higher education and crime-related programs, and therefore no support is shown for the hypothesis that increases in spending on crime-related programs led to a reduction in spending on higher education. In the education spending equation, the percentage of the population living in metropolitan areas has a negative impact on education spending, the student share of the population exerts a significant positive effect, and the rate of out-migration has a negative impact. In the crime spending equation, the contemporaneous crime rate is significant and positive and employee dominance exerts a positive and significant influence, as hypothesized. In the crime rate equation, significant influences are crime-related spending (negative, as hypothesized), the previous year's crime rate (positive), income (negative), and the unemployment rate (negative, contrary to expectations).

\section{MODEL OF HIGHER EDUCATION-CORRECTIONS SPENDING}

The argument that crime spending crowds out spending on higher education is often based on recent growth in prisons and inmates. We now estimate our model with spending on corrections (as a percentage of GSP) as a replacement for total crime-related spending so that we can examine whether this particular area of public spending crowds out spending on higher education. Spending on corrections is a sizable portion of total spending, the magnitude of which varies across the states. In 1992, the mean level of correctional spending was $0.41 \%$ of GSP and ranged from $0.19 \%$ (West Virginia) to $0.70 \%$ (Florida). For 1985 , the mean level of correctional spending was $0.29 \%$ of GSP with a range of $0.13 \%$ (North Dakota) to $0.52 \%$ (Alaska). In contrast to the rise of $21 \%$ for total crime-related spending over this period, spending of corrections rose roughly $41 \%$ over this period and therefore may potentially exert an impact that is stronger on higher education spending than on total crime-related spending.

Table 4 displays TSLS estimates of our three-equation model for 1992 and 1985 data. The first three columns display estimates for 1992. In the education spending equation, correction spending and the rate of out-migration exert negative influences on education spending and the student population exerts a positive influence. The negative coefficient on corrections spending is consistent with the crowding-out hypothesis. In the corrections spending equation, significant influences are the political party dummy variable (positive) and employee dominance(positive, as hypothesized). Estimation of the crime rate equation indicates that the previous year's crime rate exerts a significant positive influence and the percentage of the population aged 18 to 24 exerts a negative influence (contrary to expectations).

The last three columns of Table 4 display equation estimates for 1985 . The results are similar to those for 1992. No evidence of any relationship is found between higher education and corrections programs, and therefore no support is provided for the hypothesis that increases in spending on corrections lead to a reduction in spending on higher education. In the education spending equation, the percentage of the population living in metropolitan areas has a negative influence, the student share of the population exerts a significant positive effect, and the rate of population outmigration has a significant negative effect. In the corrections spending equation, the 
contemporaneous crime rate exerts a positive influence and employee dominance exerts a positive and significant influence, as hypothesized. In the crime rate equation, significant influences are income (negative), the previous year's crime rate (positive), and the unemployment rate (negative, contrary to expectations).

\section{ESTIMATIONS USING PERCENTAGE CHANGES OVER THE 1985 TO 1992 PERIOD}

Table 5 displays estimates of higher education spending, crime-related spending, corrections spending, and crime rate equations where these variables are measured as percentage changes over the 1985 to 1992 period. These equations are estimated to determine how changes in these variables over this time period influenced one another. Percentage changes in all explanatory variables also replace their levels as used in the previous estimations. These models are another approach to determining whether crime-related spending crowded out spending on education over this period. As noted earlier, the average level of public higher education spending fell as a percentage of GSP over this period, as the average levels of both total crime and corrections spending rose as percentages of GSP. Estimated relationships therefore will now contain two dimensions, cross-state and over time, and provide additional information on whether there is any linkage between these programs. Because we are now considering changes across time, three political party dummy variables must be included. For each state there are four possible outcomes regarding the governorship. A state could have had Republican governors in both years, a Democratic governor in both years, a Republican governor in 1985 and a Democratic governor in 1992, or a Democratic governor in 1985 and a Republican governor in 1992. Three dummy variables are included in the estimated equations, with the possibility of Democratic governors in both years the excluded case.

The first three columns display estimations of percentage changes in higher education spending as a percentage of GSP, total crime-related spending as a percentage of GSP, and the crime rate. The percentage change in education spending and the percentage change in crime-related spending do not have significant influences on each other. In the education spending equation, the percentage change in the student share of the population has a significant positive effect on education spending and the percentage change in the rate of out-migration has a negative effect. In the crime spending equation, the percentage change in income has a negative effect on the percentage change in crimerelated spending, and the percentage change in crime-related employees as a share of the population exerts a significant positive influence. In the crime rate equation, the previous year's crime rate exerts a significant positive influence.

The last three columns display estimations of percentage changes in education spending as a percentage of GSP, corrections spending as a percentage of GSP, and the crime rate. Percentage changes in neither spending program exert a significant influence on the other. In the education spending equation, the percentage change in the student share of the population exerts a significant positive effect on the percentage change in the share of education spending, and the percentage change in the rate of out-migration has a significant negative effect. In the corrections spending equation, the percentage change in corrections-related employees as a share of the population exerts a significant positive influence. In the crime rate equation, significant influences are the 
percentage change in the previous year's crime rate (positive) and the percentage change in median age (positive).

\section{ALTERNATIVE MEASURES OF SPENDING}

The equations were also estimated with alternative measures of public higher education spending and crime spending. Instead of measuring these expenditures as percentages of GSP, higher education spending per pupil and crime spending per capita were used. To save space, the full results are not displayed, but we discuss the results for the crowding-out issue, which is the major focus of our study. For 1992, the results show no significant relationship between higher education spending per student and crime-related spending per capita. Corrections spending per capita does not have a significant influence on education spending per student in 1992, but education spending per pupil exerts a significant negative effect on corrections spending per capita. We also find that the rate of out-migration has a significant negative impact on higher education spending per pupil when corrections spending is used in the model. Thus, for 1992, there is no evidence that crime spending crowded out education spending per pupil.

For 1985, crime-related spending per capita has no significant influence on education spending per student, but education spending per pupil has a significant positive effect on crime-related spending per capita. When crime-related spending is replaced with corrections spending, corrections spending exerts a positive influence on education spending, and higher education spending has a significant positive impact on corrections spending per capita. For 1985, there is no evidence that higher education spending per student was crowded out by crime spending. The results indicate states that spent relatively large amounts on crime also spent relatively large amounts on higher education.

When the equations are estimated with the variables measured as percentage changes between 1985 and 1992, neither higher education spending per pupil nor crime-related spending per capita exerts a significant influence on the other. No significant relationship is found between higher education spending per student and corrections spending per capita. Taken together, these results using alternative measures of higher education spending and crime spending display no evidence that increased crime spending per capita crowded out higher education spending per student.

\section{CONCLUSIONS}

Our empirical analysis provides weak evidence that crime-related programs have crowded out spending on higher education. Evidence of crowding out of education spending by both total crime spending and corrections spending is found for 1992, when these expenditures are measured as percentages of GSP; but no evidence is found for 1985 or for the period from 1985 to 1992 as a whole. But the crowding-out hypothesis is not supported by our findings when higher education spending is measured by expenditures per pupil and crime-related and corrections spending are measured as expenditure per capita. Also, as our testing indicates, no significant negative interrelationships are found over the 1985 to 1992 period for any of these programs, and therefore neither side of the spending debate can reasonably claim strong and consistent evidence that its 
spending plans are always impeded by what success the other program experiences in its spending budget.

We conclude with the caveat that, because our evidence is based on the 1985 to 1992 period and therefore does not cover a period in which states were implementing three strikes-type legislation, future relationships between spending on higher education and on crime-related programs may change to one wherein crowding out consistently occurs. This may be consistent with the empirical results that show some crowding out in 1992 but not in 1985, because the largest relative increases in spending on crime-related programs occurred nearer the end of the 1985 to 1992 period. Of course, it is possible that the increases in crime and corrections spending had a greater negative impact on budget categories of public spending other than expenditures at public institutions of higher education. For example, social services budgets and public spending on recreation may have experienced more severe reductions in spending than higher education, but whether they actually did is a question for future research to determine. 


\section{NOTES}

1. See, for example, Barr (1995) for a discussion of the possible impacts of California's "three strikes and you are out" law on education spending.

2. For example, California's Proposition 98 guarantees that schools and community colleges receive a minimum amount of revenue from state and local property taxes. The allocation guarantee is based on a formula involving enrollment changes and projections of state tax revenues.

3. Notice that the connection between education spending and program quality is ambiguous, as higher education spending could simply reflect higher compensation for school personnel, but it could also reflect higher quality programs. However, for our purposes, we are only interested in education spending because this appears to be the focus of the crime-education debate.

4. We have included student to control for the demand for higher education under the assumption that this variable reflects voter demand for maintaining or raising existing levels of higher education spending. We predict then that higher values of student lead to higher spending, either as a share of GSP or per student. There is, however, an endogeneity concern when higher spending states foster a larger student body because they offer higher quality programs and/or lower tuition. In this case, larger values of dependent variables (spending) may lead to higher values of student.

5. There is some evidence that past school district consolidation has not exploited scale economies. Kenny and Schmidt (1994) found that numbers of school districts in states are always substantially greater than numbers that would be predicted based solely on attempts to gain greater scale economies.

6. We have not included spending of private universities of higher education because it is not entirely clear what effect such spending would have on public spending on higher education. It is unclear, for instance, whether state legislatures consider private spending on higher education when they set public budgets on higher education. Moreover, the degree to which private universities are educating students from out of state is unclear, and substantial variation is likely to exist across states in the degree to which private universities educate within-state students.

7. The authors are indebted to an anonymous referee for suggesting this variable.

8. Details of the two-stage least squares (TSLS) procedures can be found in most standard econometrics textbooks.

9. We also estimated the equations with the rate of population immigration included as an explanatory variable. It is not included in the results because the rate of in-migration was not found to be statistically significant in any of the equations and its inclusion had no effect on the results reported in the article.

10. Note that, rather than the total number of crime-related employees, this variable is the number of employees in corrections as a percentage of the population.

11. Unlike the estimations with education as a share of gross state product (GSP), income displays a positive and significant influence on education per pupil for both years and for both total justice spending and corrections spending equations. 


\section{REFERENCES}

1. Barr, Loren L. 1995. The "three strikes" dilemma: Crime reduction at any price? Santa Clara Law Review 36:107-50.

2. Brazer, Harvey, and Therese McCarty. 1987. Interaction between demand for education and for municipal services. National Tax Journal 40:555-66.

3. Brennan, G., and J. M. Buchanan. 1980. The power to tax: Analytical foundations of a fiscal constitution. Cambridge, UK: Cambridge University Press.

4. Bureau of Justice Statistics. 1997, January. Justice expenditure and employment extracts, 1992. Washington, DC: U.S. Department of Justice.

5. Bureau of Justice Statistics. n.d. Sourcebook of criminal justice statistics. Washington, DC: U.S. Department of Justice. (Selected years)

6. Clotfelter, Charles T. 1976. Public spending for higher education: An empirical test of two hypotheses. Public Finance/Finances Publiques 31:177-95.

7. Fossett, James W., and James H. Wykoff. 1996. Has Medicaid growth crowded out state educational spending? Journal of Health Politics, Policy and Law 21:409-32.

8. Greenwood, Peter W., C. Peter Rydell, Allan F. Abrahamse, Jonathan P. Caulkins, James R. Chiesa, Karyn E. Model, and Stephen P. Klein. 1994. Three strikes and you're out. Santa Monica, CA: RAND.

9. Hoenack, S., and D. Pierro. 1990. An econometric model of a public university's income and enrollments. Journal of Economic Behavior and Organization 14:403-23.

10. Kenny, L. W., and A. B. Schmidt. 1994. The decline in the number of school districts in the U.S.: 1950-1980. Public Choice 79:1-18.

11. McCarty, Therese A., and Stephen J. Schmidt. 1997. A vector autoregression analysis of state government expenditure (Papers and proceedings). American Economic Review 87 (May): 27882.

12. National Center for Education Statistics. 1992, 1993. Digest of education statistics. Washington, DC: U.S. Department of Education.

13. Strathman, James G. 1994. Migration, benefit spillovers and state support of higher education. Urban Studies 31:913-20.

14. Toutkoushian, Robert K., and Paula Hollis. 1998. Using panel data to examine legislative demand for higher education. Education Economics 6:141-57.

15. U.S. Department of Commerce. n.d. Statistical abstracts of the United States. Washington, DC:

16. U.S. Department of Commerce. (Selected dates) 


\section{TABLES}

TABLE 1

TABLE 1: Definitions

\begin{tabular}{|c|c|}
\hline Variable & Definition \\
\hline $\operatorname{EDEXP}_{j}$ & $\begin{array}{l}\text { Current-fund expenditures of public higher education, per pupil or } \\
\text { as a percentage of gross state product. These expenditures are } \\
\text { funded from various sources. }\end{array}$ \\
\hline $\mathrm{CRIME}_{j}$ & $\begin{array}{l}\text { Total crime-related expenditures of state and local governments, } \\
\text { per capita or as a percentage of gross state product. Includes } \\
\text { expenditures for police protection, judicial, legal services and } \\
\text { prosecution, public defense expenditure, corrections expendi- } \\
\text { ture, and other justice expenditure. }\end{array}$ \\
\hline$Y_{i}$ & Median family income of the population. \\
\hline $\mathrm{EDUC}_{j}$ & Percentage of population with high school degree or higher. \\
\hline METRO & Percentage of population living in metropolitan areas. \\
\hline STUDENT $_{j}$ & Higher education student percentage of population. \\
\hline COLLEGES & $\begin{array}{l}\text { Number of public institutions of higher education and branches per } \\
1,000 \text { students. }\end{array}$ \\
\hline DIVERSITY & $\begin{array}{l}\text { Index of racial/ethnic diversity; the higher the value, the less diverse } \\
\text { the population. }\end{array}$ \\
\hline OUTRATE $_{j}$ & $\begin{array}{l}\text { Outmigration rate, the number of out-migrants over } 5 \text { years per } \\
1,000 \text { population at the beginning year. }\end{array}$ \\
\hline PARTY, & $\begin{array}{l}\text { A dummy variable equal to } 1 \text { if the govemor of the state was a Re- } \\
\text { publican and } 0 \text { if the governor was a Democrat. }\end{array}$ \\
\hline $\mathrm{CR}_{j}$ & $\begin{array}{l}\text { Crime offenses known to police per } 100,000 \text { population; includes } \\
\text { both violent and property crime. }\end{array}$ \\
\hline $\mathrm{CCR}_{i}$ & Change in crime rate, 1992 less 1985. \\
\hline MEDA & Median age of population. \\
\hline MID1; & Percentage of population aged $18-24$. \\
\hline $\mathrm{MID}_{j}$ & Percentage of population aged 25-44. \\
\hline $\mathrm{DOM}_{i}$ & $\begin{array}{l}\text { Percentage of justice-related employees in population; includes po } \\
\text { lice protection, judicial, legal services and prosecution, public } \\
\text { defense, corrections, and other justice employees. }\end{array}$ \\
\hline $\mathrm{UE}_{j}$ & Civilian unemployment rate. \\
\hline $\mathrm{CUE}_{j}$ & Change in civilian unemployment rate, 1992 less 1985. \\
\hline
\end{tabular}




\section{TABLE 2}

TABLE 2: Summary Statistics of Key Variables

\begin{tabular}{|c|c|c|c|c|}
\hline Variable & Mean & Median & Minimum & Maximum \\
\hline \multicolumn{5}{|l|}{1992} \\
\hline Crime-related spending ( $\%$ of GSP) & 1.17 & 1.11 & 0.69 & 1.92 \\
\hline Corrections-related spending ( $\%$ of GSP) & 0.41 & 0.40 & 0.19 & 0.70 \\
\hline Higher education spending ( $\%$ of GSP) & 1.96 & 1.95 & 0.99 & 3.36 \\
\hline Crime rate (per 100,000 population) & 5,085 & 5,081 & 2,610 & 8,358 \\
\hline Median household income (\$) & 30,720 & 30,278 & 42,171 & 20,301 \\
\hline$\%$ population with high school degree or higher, 1990 & 76.3 & 76.8 & 64.3 & 86.6 \\
\hline$\%$ population in metropolitan areas & 66.7 & 69.6 & 24 & 100 \\
\hline$\%$ student share of population & 4.47 & 4.31 & 2.95 & 6.72 \\
\hline Numbers of colleges per 1,000 students & 0.25 & 0.22 & 0.11 & 0.48 \\
\hline Diversity index & 6,930 & 7,026 & 3,864 & 9,624 \\
\hline Out-migration rate (per 1,000 population) & 0.11 & 0.10 & 0.07 & 0.29 \\
\hline Median age of population (years) & 33.5 & 33.6 & 26.6 & 36.6 \\
\hline Population share aged $18-24$ & 10.13 & 10.05 & 8.82 & 11.74 \\
\hline Population share aged $25-44$ & 31.88 & 31.78 & 28.80 & 37.64 \\
\hline Crime employees as share of population & 0.56 & 0.55 & 0.34 & 0.85 \\
\hline Correctional employees (share of population) & 0.19 & 0.18 & 0.08 & 0.33 \\
\hline \multicolumn{5}{|l|}{1985} \\
\hline Crime-related spending ( $\%$ of GSP) & 0.97 & 0.93 & 0.64 & 1.50 \\
\hline Corrections-related spending ( $\%$ of GSP) & 0.29 & 0.27 & 0.13 & 0.52 \\
\hline Higher education spending ( $\%$ of GSP) & 1.72 & 1.71 & 0.86 & 2.80 \\
\hline Crime rate (per 100,000 population) & 4,753 & 4,627 & 2,253 & 7,574 \\
\hline Median household income (\$) & 32,877 & 32,339 & 22,638 & 49,264 \\
\hline$\%$ population with high school degree or higher, 1980 & 67.5 & 68.0 & 53.1 & 82.5 \\
\hline$\%$ population in metropolitan areas & 63.4 & 66.4 & 19.1 & 100 \\
\hline Student share of population & 3.96 & 3.95 & 2.50 & 6.35 \\
\hline Numbers of schools per 1,000 students & 0.28 & 0.24 & 0.11 & 0.89 \\
\hline Diversity index & 7,247 & 7,314 & 4,134 & 9,681 \\
\hline Out-migration rate (per 1,000 population) & 0.13 & 0.11 & 0.06 & 0.41 \\
\hline Median age of population (years) & 31.1 & 31.2 & 25.4 & 35.5 \\
\hline Population share aged $18-24$ & 12.1 & 12.1 & 10.4 & 13.3 \\
\hline Population share aged 25-44 & 30.7 & 30.5 & 27.1 & 38.9 \\
\hline Crime employees as share of population & 0.50 & 0.46 & 0.34 & 0.80 \\
\hline \multicolumn{5}{|l|}{ Correctional employees as } \\
\hline share of population & 0.14 & 0.13 & 0.07 & 0.25 \\
\hline
\end{tabular}




\section{TABLE 3}

TABLE 3: Two-Stage Least Squares Estimations of Higher Education Spending, Total Crime Spending, and Crime Rate Equations

\begin{tabular}{|c|c|c|c|c|c|c|c|c|c|c|c|c|}
\hline \multirow{3}{*}{$\frac{\text { Variable }}{\text { Constant }}$} & \multicolumn{6}{|c|}{1992} & \multicolumn{6}{|c|}{1985} \\
\hline & \multicolumn{2}{|c|}{ Education Spending } & \multicolumn{2}{|c|}{ Crime Spending } & \multicolumn{2}{|c|}{ Crime Rate } & \multicolumn{2}{|c|}{ Education Spending } & \multicolumn{2}{|c|}{ Crime Spending } & \multicolumn{2}{|c|}{ Crime Rate } \\
\hline & 1.87 & $(1.60)$ & 0.17 & $(0.58)$ & $4,102.5$ & $(1.28)$ & $1.72^{\star \star}$ & $(2.56)$ & -0.05 & $(0.23)$ & $3,435.8^{* *}$ & (2.19) \\
\hline Crime spending & $-0.99^{\star \star}$ & $(2.08)$ & & & 1.69 & $(0.46)$ & -0.64 & $(1.29)$ & & & $-642.5^{\star \star \star}$ & $(2.02)$ \\
\hline Education spending & -0.06 & $(0.91)$ & & & & & & & 0.09 & $(1.60)$ & & \\
\hline Income & $-2.31 \mathrm{E}-05$ & $(0.85)$ & $-5.35 \mathrm{E}-07$ & $7(0.10)$ & -0.01 & $(0.61)$ & 2.84E-06 & $(0.17)$ & $5.28 \mathrm{E}-07$ & $(0.13)$ & $-0.01^{\star \star \star}$ & $(1.73)$ \\
\hline Education & 0.03 & $(0.92)$ & & & & & 0.008 & $(0.54)$ & & & & \\
\hline Metro & -0.01 & $(1.04)$ & & & & & $-0.01^{\star *}$ & (2.49) & & & & \\
\hline Student & $0.35^{*}$ & (3.65) & & & & & $0.03^{*}$ & $(4.36)$ & & & & \\
\hline Colleges & -0.21 & $(0.22)$ & & & & & -0.16 & $(0.70)$ & & & & \\
\hline Diversity & $-8.88 \mathrm{E}-05$ & $(1.11)$ & & & -0.04 & $(0.92)$ & $-1.49 \mathrm{E}-05$ & $(0.25)$ & -0.03 & $(1.06)$ & & \\
\hline Out-migration & -4.35 & $(1.54)$ & & & & & $-4.44^{*}$ & $(3.04)$ & & & & \\
\hline Republican dummy & 0.21 & $(1.37)$ & $0.12^{\star \star}$ & $(2.33)$ & & & -0.09 & $(0.80)$ & -0.03 & $(0.77)$ & & \\
\hline Crime rate & & & $8.33 \mathrm{E}-05$ & $5^{\star}(2.72)$ & & & & & $7.32 \mathrm{E}-05^{+}$ & * (3.37) & & \\
\hline Crime rate lagged & & & & & $0.87^{\star}$ & $(13.4)$ & & & & & $1.16^{\star}(2$ & 22.4) \\
\hline \multicolumn{12}{|l|}{ 3-year crime } & \\
\hline Median age & & & & & -48.7 & $(1.09)$ & & & & & -16.01 & $(0.72)$ \\
\hline Population aged 18-24 & & & & & -158.1 & (1.47) & & & & & -105.6 & $(1.67)$ \\
\hline Population aged $25-44$ & & & & & 0.73 & $(0.02)$ & & & & & -19.26 & $(0.88)$ \\
\hline Employee dominance & & & $0.12^{*}$ & (3.11) & & & & & $0.10^{*}$ & $(3.03)$ & & \\
\hline Unemployment rate & & & & & 5.59 & $(0.13)$ & & & & & $-49.88^{\star \star}$ & (2.62) \\
\hline \multicolumn{5}{|c|}{3 -year change in unemployment rate } & -42.5 & $(0.59)$ & & & 14.7 & $(0.64)$ & & \\
\hline Adjusted $R^{2}$ & & 0.38 & & 0.65 & & 0.95 & 0. & & 0. & 66 & & .97 \\
\hline SEE & & 0.48 & & 0.17 & & 67.0 & 0. & & 0. & 12 & 204. & \\
\hline$F$ & & $5.09^{*}$ & & $16.7^{\star}$ & & $09.0^{*}$ & & $38^{\star}$ & 14. & $16^{*}$ & 213. & \\
\hline
\end{tabular}

NOTE: Data are coefficients, with $t$ statistics in parentheses. Cells containing $E$ are exponentials. SEE $=$ standard error of estimate. ${ }^{\star} p \leq .01 .{ }^{\star \star} p \leq .05 .{ }^{* \star} p \leq .10$. 


\section{TABLE 4}

TABLE 4: Two-Stage Least Squares Estimations of Higher Education Spending, Corrections Spending, and Crime Rate Equations

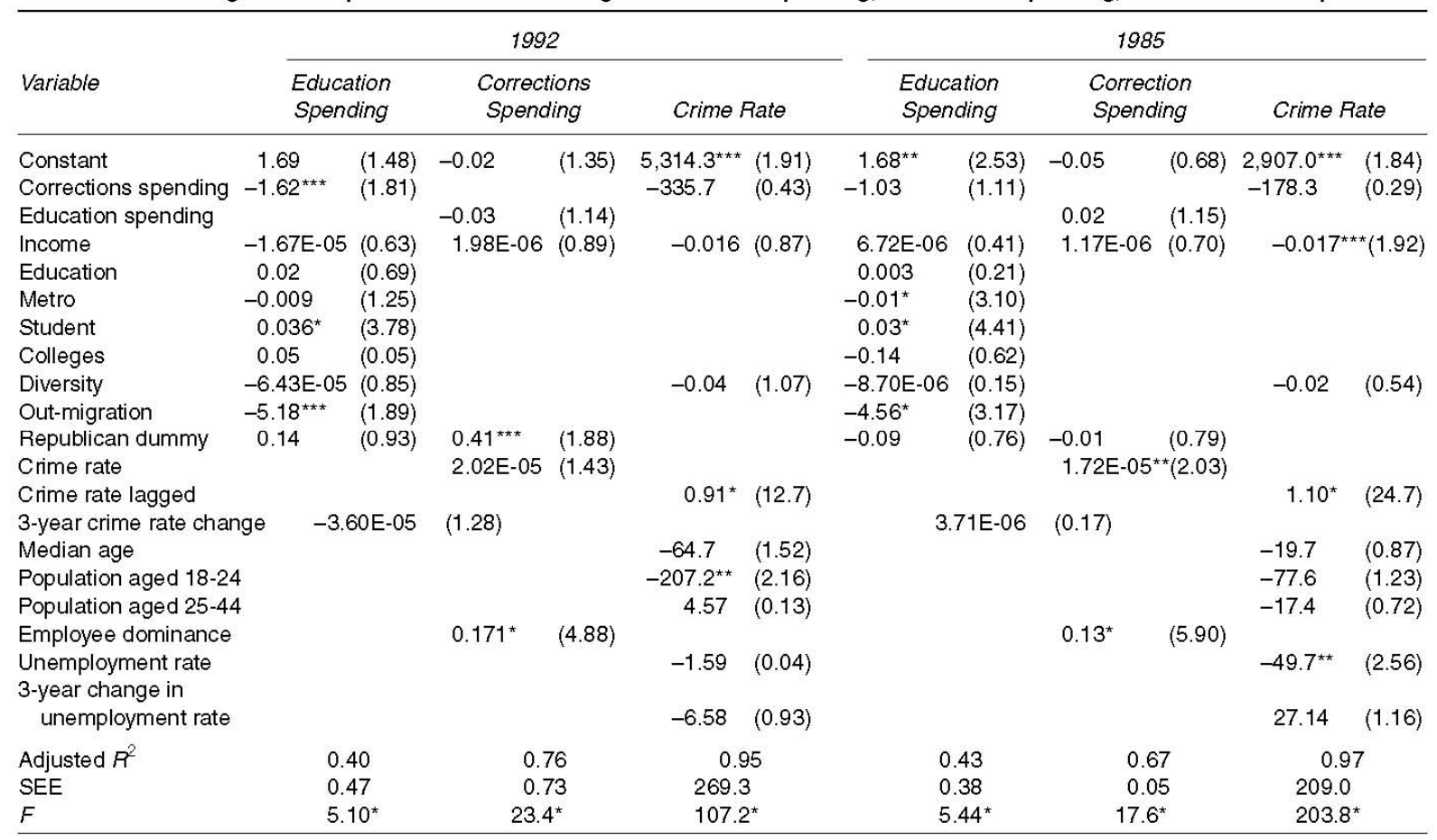

NOTE: Data are coefficients, with $t$ statistics in parentheses. Data containing $E$ are exponentials. SEE $=$ standard error of estimate. ${ }^{*} p \leq .01 .{ }^{* \star} p \leq .05 .{ }^{* \star} p \leq .10$. 


\section{TABLE 5}

TABLE 5: Two-Stage Least Squares Estimations of Higher Education Spending, Total Crime Spending, and Crime Rate Equations: Percentage Changes, 1985-1992

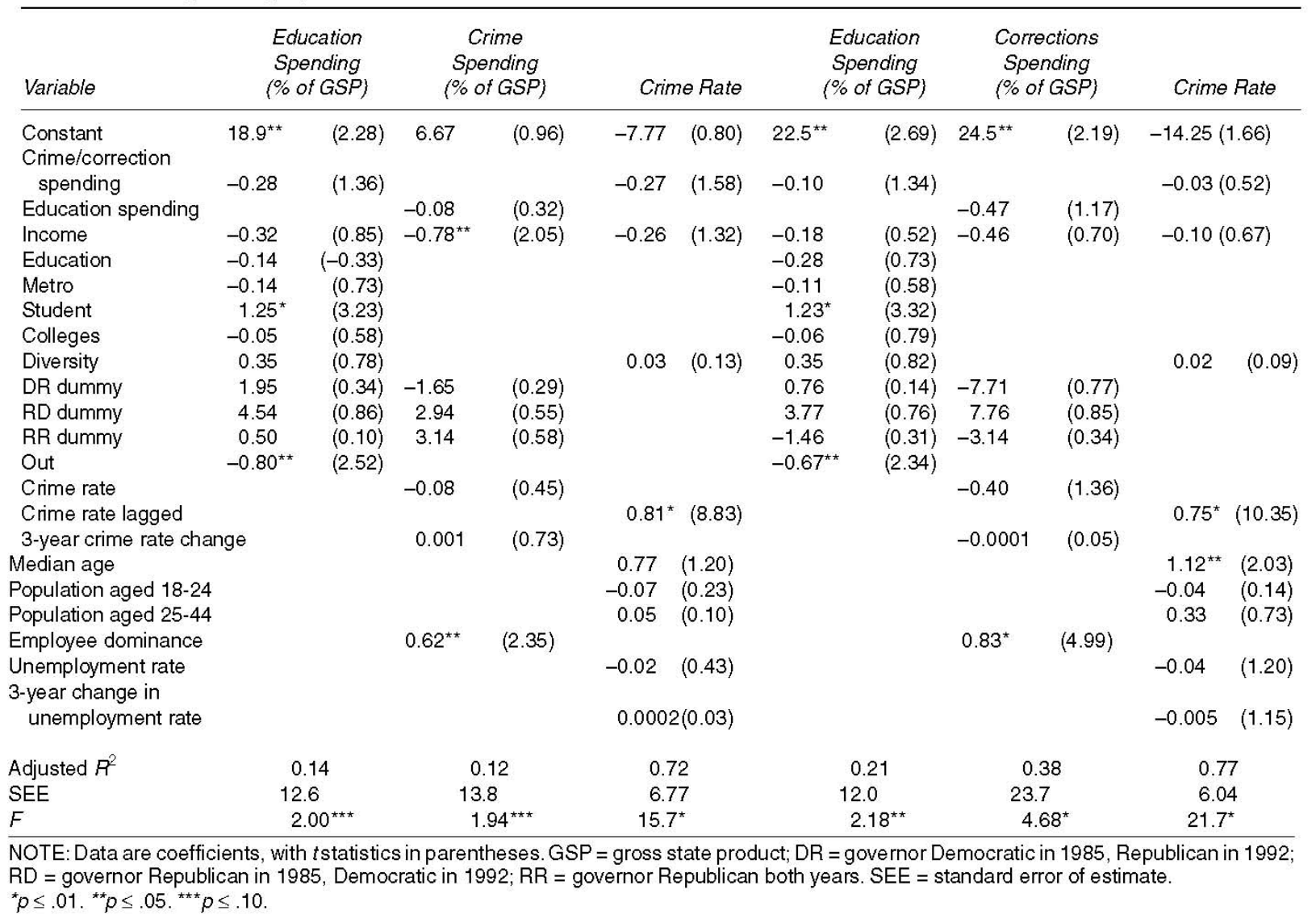

